\title{
ORGANIC FERTILIZATION TO INCREASE THE PRODUCTIVITY OF THE LIMA BEANS (Phaseolus lunatus L.)
}

\section{Demichaelmax Sales de Melo' ${ }^{1}$ José Marcelino da Silva Junior ${ }^{2}$, José Kennedy do Nascimento Ribeiro $^{2}$, Mácio Farias de Moura ${ }^{2}$ and José Carlos da Costa ${ }^{3}$}

1Universidade Federal da Paraíba, Areia/PB, Brasil; ²Universidade Federal do Agreste de Pernambuco, Garanhuns/PE, Brasil; ${ }^{3}$ Instituto Federal de Educação de Pernambuco, Vitória de Santo Antão/PE, Brasil

\section{ARTICLE INFO}

\section{Article History:}

Received $11^{\text {th }}$ December, 2020

Received in revised form

$28^{\text {th }}$ December, 2020

Accepted $06^{\text {th }}$ January, 2021

Published online $28^{\text {th }}$ February, 2021

\section{Key Words:}

Water Resources;

Environmental Economics; Beer.

*Corresponding author:

Demichaelmax Sales de Melo

\begin{abstract}
The present work had as objective to evaluate the yield of two varieties of fava in function of application of organic compost and dairy waste. The experiment was carried out at the Experimental Farm belonging to the Federal Rural University of Pernambuco (UFRPE). The experiment was carried out in a randomized block design in a factorial scheme $[(2 \times 3)+4]$, with two varieties of Lima bean, three forms of organic fertilization plus four additional controls, in three repetitions. Data were subjected to analysis of variance and treatment means, compared by the Tukey test $(\mathrm{P}<0.05)$. Dunnett's test was also used for comparisons involving additional witnesses and other treatments. The software used for statistical analysis was SAEG 9.1 and SAS 9.0. Dairy waste was the fertilizer that most contributed to the increase in productivity, making it suitable for use as fertilizer. The Branquinha variety is indicated for production, because it responded better to the types of fertilizers used.
\end{abstract}

Copyright (C) 2021, Demichaelmax Sales de Melo. This is an open access article distributed under the Creative Commons Attribution License, which permits unrestricted use, distribution, and reproduction in any medium, provided the original work is properly cited.

Citation: Demichaelmax Sales de Melo. 2021. "Organic fertilization to increase the productivity of the lima beans (phaseolus lunatusl.)", international journal of development research, 11, (02), 44666-44672.

\section{INTRODUCTION}

Limabeans (Phaseolus lunatus L.), belong to the Fabacea family and originate in the South American Andes (MOTTA-ALDANA et al. 2013). Has presents epigeal germination, small and pointed bracteoles, oblong and flat pods with seed number varying between two to four (PEGADO, 2008; SANTOS et al. 2002). This crop stands out in the Northeast of Brazilfor its rusticity, produced with low rainfall and harvest in the dry period (AZEVEDO et al., 2003). It is more cultivated by family farming, which generally applies little technology to produce, resulting in low productivity rates (OLIVEIRA et al. 2014). According to IBGE (2018) 11,828 tons of lima beansgrains were produced in Brazil in an area of 37,209 hectares, with an average yield of $328 \mathrm{~kg} \mathrm{ha}^{-1}$. The states of the Northeast region are the main responsible for this production (IBGE, 2018).Low productivity is related, among other factors, to the low use of fertilizers. For Santos et al. (2009), fertilization is a basic condition for maintaining soil fertility at satisfactory levels, allowing for profitable agricultural production. The correction of soil fertility aims to increase the levels of macronutrients, nitrogen, phosphorus and potassium, which often occurs through the use of mineral fertilizers (VALE et al., 2017). Use of chemical fertilizers can favor the leaching of mineral elements and the consequent transport to the deepest layers of the soil. Excessive quantities result in increased production costs and damage to the environment (ARAÚJO et al., 2010).
To reduce the impact of mineral fertilizers on the environment, there are organic fertilizers, of lower cost, and benefit already guaranteed in the research of physics, chemistry and soil biology. The organic compound comes from the fermentation of bovine manure and vegetable remains, is rich in mineral nutrients and widely used in agricultural production (FÉLIX, 2014). For this fertilizer to have its potentiated effects, it is necessary to provide moisture and temperature for microorganisms responsible for the composting process (SILVA et al. 2018). Wastes from the dairy industry are biosolids, rich in organic matter and essential nutrients for plant growth and a sustainable option as a fertilizer and soil conditioner. It comes from Sewage Treatment Stations (STS) generated from the process of processing the milk and cleaning the facilities. However, it presents considerable levels of phosphorus and potassium, these can vary depending on the processing of milk (MELO et al., 2011). Currently, there is a demand for sustainable forms of soil fertilization (YANG et al., 2015). Thus, the present study aimed to evaluate the yield of two varieties of lima beans according to the application of organic fertilizers.

\section{MATERIALS AND METHODS}

The experiment was carried out at the Experimental Farm belonging to the Federal Rural University of Pernambuco (UFRPE), located at latitude $08^{\circ} 58^{\prime} 28$ "S and longitude $36^{\circ} 27^{\prime} 11$ " O, altitude $736 \mathrm{~m}$. 
The region has a predominance of high-altitude mesothermal tropical climate (Cs'a), according to the Köppen-Geiger classification (CPRM, 2007; MELO and ALMEIDA, 2013). The soil has physical characteristics FRANCO ARENOSO is classified as YELLOW ARGISSOLO (SANTOS et al., 2018). Precipitation (Figure 1) and temperature (Figure 2) were recorded during the experiment at a meteorological station at the experimental station - UFRPE / UAG.

Treatments and experimental design: The experiment was carried out in an area of $510 \mathrm{~m}^{2}$, divided into three blocks, into 10 plots measuring $15 \mathrm{~m}^{2}$ each. The treatments consisted of two varieties of lima beans, Branquinha (B) and Roxinha (R), fertilized with organic fertilizers: Dairy waste (DW), Organic Compound (OC) and four additional witnesses, two with mineral treatment (MT), (B + MT and $\mathrm{R}+\mathrm{MT})$ and two Absolute treatment(AT), $(\mathrm{B}+\mathrm{AT}$ and $\mathrm{R}+\mathrm{AT})$ characterized by the absence of fertilization. An intermediate treatment was also used with half the dose of each organic fertilizer $(\mathrm{DW}+\mathrm{OC})$.

Chemical property of the soil: Chemical analysis of the soil of the plots was carried out to apply the treatments (Table 1) and $\mathrm{pH}$ and phosphorus deficiency correction with sugarcane bagasse ash 30 days before the experiment was carried out.The calculation for correction was based on the phosphorus content of the ash (Table 2) and the crop requirement. It was applied approximately $1.33 \mathrm{~kg} . \mathrm{m}^{-2}$ of sugarcane bagasse ash.Since there was no fertilization recommendation for the culture of lima beans (Phaseolus lunatus) for the State of Pernambuco, we used the recommendation for the culture of irrigated beans (Phaseolus vulgaris) as a basis, according to the fertilization recommendation manual of the State of Pernambuco (IPA, 2008).

Organic fertilization: For organic fertilization, the dairy waste was collected in the solid phase in DPA-Nestlé unit in Garanhuns-PE. Approximately $1.8 \mathrm{~kg} \cdot \mathrm{m}^{-2}$ is equivalent to the need for nitrogen $(\mathrm{N})$ by the culture. The application of dairy waste was dimensioned according to the subsurface application rate defined by resolution $375 / 2006$ - CONAMA. Fertilization with organic compost was carried out with $0.30 \mathrm{~kg} \cdot \mathrm{m}^{-2}$, meeting the nutritional need for $\mathrm{N}$ by the crop, following the fertilization recommendation manual of the State of Pernambuco (IPA, 2008).

Conventional fertilization: Treatment characterized by receiving mineral fertilizer, were applied equivalent to $40 \mathrm{~kg}^{-h^{-1}}$ of $\mathrm{N}, 80$ kg.ha ${ }^{-1}$ of $\mathrm{P}_{2} \mathrm{O}_{5}$ and $80 \mathrm{~kg} \cdot \mathrm{ha}^{-1}$ of $\mathrm{K}_{2} \mathrm{O}$ at the time of planting, according to the fertilization recommendation manual. for the State of Pernambuco (IPA, 2008) for the cultivation of irrigated beans.

Experimental driving: The plots were dimensioned in an area of 15 $\mathrm{m}^{2}$, corresponding to $5 \mathrm{~m}$ wide by $3 \mathrm{~m}$ long. Two varieties of lima bean (Phaseolus lunatus L.), known as Branquinha and Roxinha, were planted, with semi prostatic size and undetermined growth. Sowing was carried out in pits with spacing of $1.0 \times 0.5 \mathrm{~m}$ and density of 6 plants per square meter available in 60 thousand plants $\mathrm{ha}^{-1}$. A useful area of $3 \mathrm{~m}^{2}$ was considered to evaluate productivity and 10 plants in the area were selected. During sowing, twice as many seeds were used to define the density, 15 days after emergence (DAE), manual thinning of six plants per linear meter was carried out and at 60 DAE staking was done. The irrigation of the plants was carried out when there was no natural precipitation, applying approximately $3 \mathrm{~mm}$ per day, using drip irrigation. To control the development of spontaneous plants, weeding was performed whenever necessary.

Variables analyzed: Soil samples were collected from each plot at a depth of 0-20 to post harvest and then sent for chemical analysis in the laboratory. For biometric analysis, 10 plants were selected from the useful area of the plots and collected from the dry pods and grains to obtain the values of the analyzed variables. However, for Dry Mass, the previously selected plants were collected at the end of the crop cycle.

\section{Biometric traits}

- $\quad$ Dry matter: determined from the plants in the usable area after being placed to dry in an air circulation greenhouse at $65^{\circ} \mathrm{C}$ until reaching constant weight, using an analytical balance. The results were expressed in kilograms per hectare;

- $\quad$ Pods length and width: The length and width of the pods was measured with a graduated ruler. The results were expressed in centimeters;

- Number of pods/plants: Ratio obtained between the count of all the pods obtained from the useful area and the number of plants;

- Number of grains/plants: Ratio obtained between the count of all grains obtained from the useful area and the number of plants;

- weight of 100 grains: obtained by weighing 100 grains in an analytical balance. The result was expressed in grams $(\mathrm{g})$;

- Productivity: After manual lima bean threshing, the beans were weighed and then the productivity was calculated, with the data transformed to $\mathrm{kg}$ per hectare at $13 \%$ humidity (BRAZIL 2009).

Data analysis: The data were submitted to analysis of variance and means of treatment compared by the Tukey test $(\mathrm{P}<0.05)$. The Dunnett test was also used for comparisons involving additional witnesses and treatments. The software used for statistical analysis was SAEG 9.1 and SAS 9.0.

\section{RESULTS}

Chemical property of the soil: It was observed a raise in nutrient levels when fertilizers were added (Table 6).

Biometric traits: The organic fertilizers did not influence the pod length (PL) of the two varieties of limabeans studied, but when comparing the made of variety in each type of fertilizer, it can be seen that the Branquinha obtained pods with larger size (Table 7). Assessing the pod width (PW), the highest value was reached with the application of the dairy waste fertilizer (DW) in Branquinha, differing statistically from that verified in the plots fertilized with organic compound (OC), already in the Roxinha kind, the width was statistically equal regardless of the type of fertilizer used. When the comparison between the varieties was made, it was noticed that both have similar pod widths, and there was no statistical difference between them (Table 7). The dry matter of the plant (DM) has not been altered by organic fertilization or by the varieties evaluated (Table 7). For the number of pods per plant (NP), the fertilization with the dairy waste in the Branquinha variety provided better results, differing statistically from the treatment that received organic compost. The application of fertilizers for the Roxinha variety did not influence this variable (Table 7).

The Branquinha presented highest numbers of grains per plant when the dairy waste was used. Regarding Roxinha variety the different types of fertilizers did not influence the amount of grains obtained. Branquinha variety showed superior number of grains compared to Roxinha when it was fertilized with dairy waste (Table 7). The different fertilizations studied did not provide statistical difference in $\mathrm{W} 100 \mathrm{G}$ for the two analyzed varieties. Branquinhawas superior to Roxinha, presenting a significant difference for $\mathrm{W} 100 \mathrm{G}$ regardless the type of fertilization (Table 7).

Effects of organic fertilization on productivity: The productivity of lima beans varieties as a function of organic fertilizers is shown in Table 8 , it should be noted that for the Branquinha variety, this variable was increased by fertilization with dairy waste higher than fertilization with organic compost. Roxinha kind showed no statistical difference as to the types of fertilizers.

Comparison of organic fertilizers with witnesses: In table 9, we find the values pods length (PL), pods width (PW), dry matter (DM), number of pods per plant (NVP), number of grains per plant (NG), weight of 100 grains (W100G) and productivity (PRODUC), obtained by applying organic fertilizers to the Branquinha variety compared to its cultivation without the use of fertilizer. 


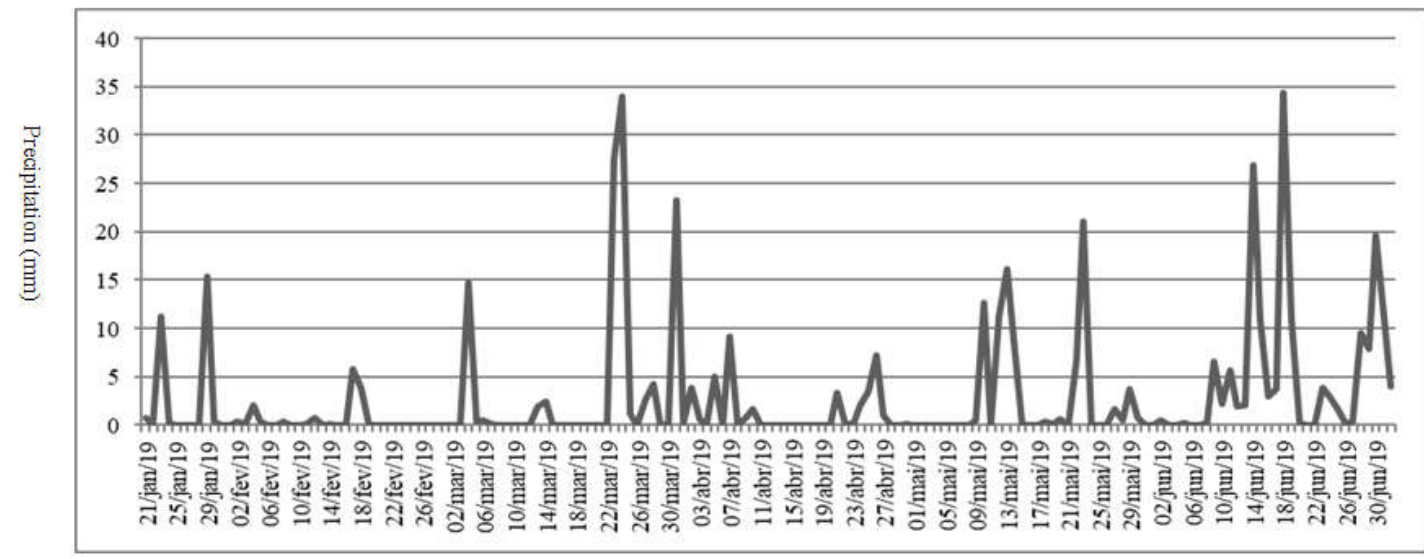

Figure 1. Precipitation during the study period Source: Weather station of the experimental station - UFRPE/UAG Garanhuns-PE, 2019

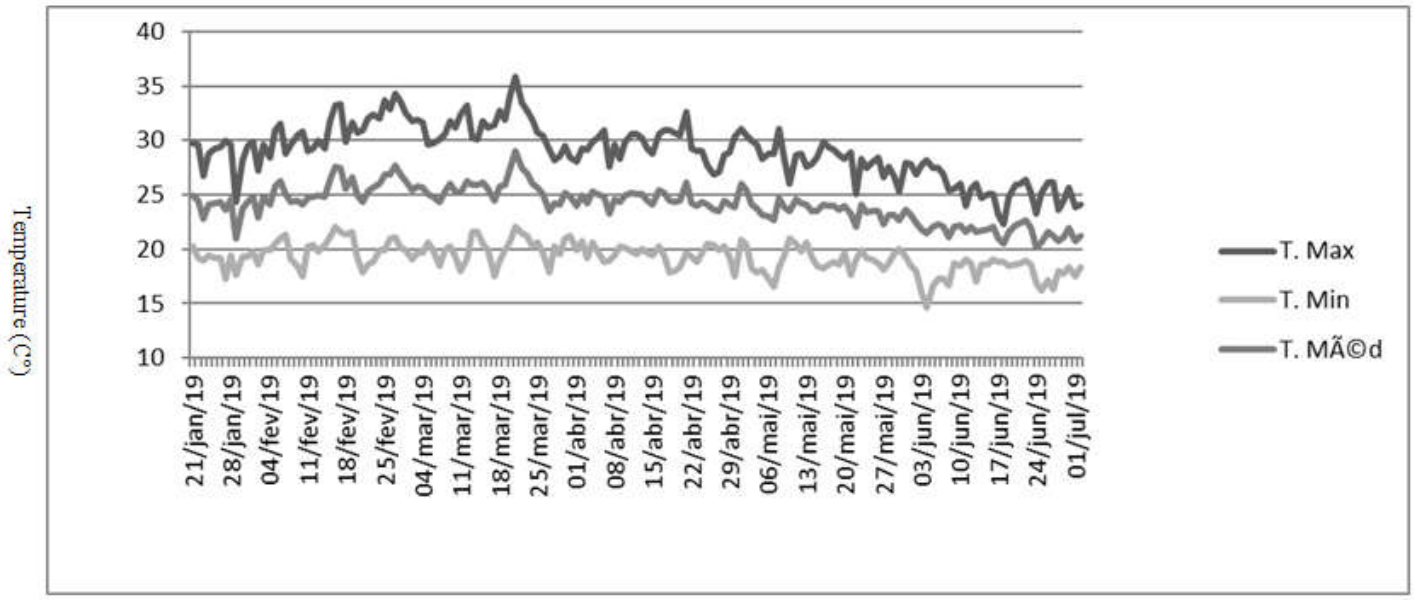

Figure 2. Temperature during the study period Source: Weather station of the experimental station - UFRPE/UAG. Garanhuns-PE, 2019.

Table 1. Soil chemical analysis

\begin{tabular}{llllllllll}
\hline $\mathrm{P}$ & $\mathrm{pH}$ & $\mathrm{Ca}$ & $\mathrm{Mg}$ & $\mathrm{H}+\mathrm{Al}$ & $\mathrm{K}$ & $\mathrm{Al}$ & $\mathrm{CTC}$ & $\mathrm{V}$ & $\mathrm{O} . \mathrm{M}$ \\
\hline $\mathrm{mg} / \mathrm{dm}^{3}$ & $(\mathrm{CaCl})$ & $----\mathrm{cmol} / \mathrm{dm}---$ & $--0,3$ & \\
2,0 & 5,0 & 1,3 & 0,3 & 2,1 & 0,184 & 0,0 & 3,88 & 46 & 1,2 \\
\hline
\end{tabular}

O.M- organicmatter. Source: Laboratório Terra análises para agropecuária Ltda., Goiânia-GO.

Table 2. Chemical analysis of sugarcane bagasse ash

\begin{tabular}{|c|c|c|c|c|c|}
\hline $\mathrm{pH}$ & Mater Org. & $\mathrm{N}$ & $\mathrm{P}$ & $\mathrm{K}$ & $\mathrm{Ca}$ \\
\hline 10,4 & 8,7 & 0,1 & 1,12 & 3,96 & 10,70 \\
\hline $\mathrm{Mg}$ & $\mathrm{S}$ & $\begin{array}{l}\mathrm{Cu} \\
\mathrm{mg} / \mathrm{Kg}\end{array}$ & $\mathrm{Fe}$ & $\mathrm{Mn}$ & $\mathrm{Zn}$ \\
\hline 2,00 & 1,28 & 261 & 241000 & 1200 & 239 \\
\hline
\end{tabular}

Source: LaboratórioTerra análise para agropecuária Ltda., Goiânia-GO.

Table 6. Mean values of the soil chemical analysis after the harvest of the experiment

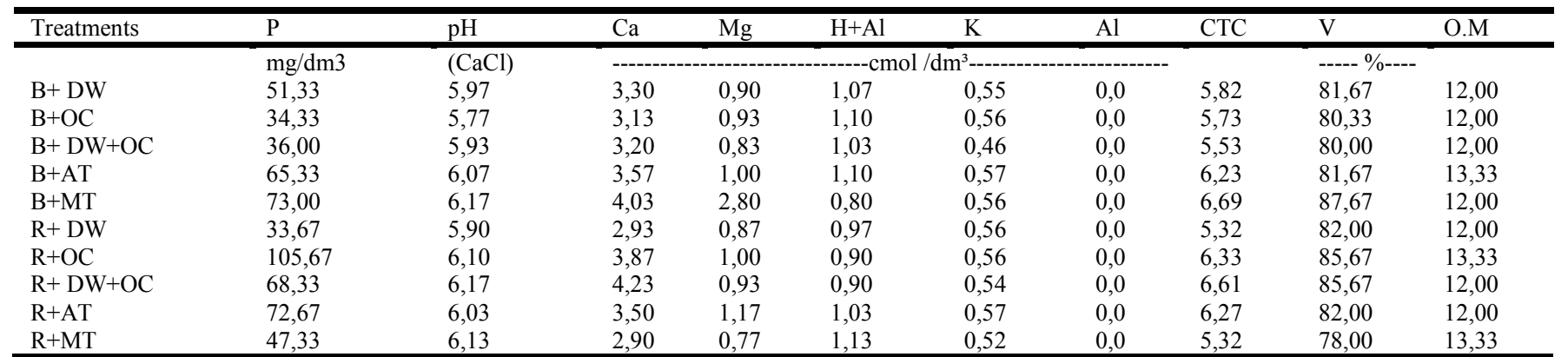

O.M-organicmatter. Source: Laboratório Terra análise para agropecuária Ltda. B=Branquinhakind, $\mathrm{R}=$ Roxinhakind; DW=Dairy waste, $\mathrm{OC}=\mathrm{Organic}$ compound, $\mathrm{DW}+\mathrm{OC}=$ Dairy waste + Organic compound, $\mathrm{AT}=$ Absolute treatment, $\mathrm{MT}=$ Mineral treatment. 
It is observed that for these variables there was no statistical difference when applying organic fertilizers in absolute control. Table 9. Pods length (PL), pods width (PW), dry matter (DM), number of pods per plant (NP), number of grains per plant (NG), weight of 100 grains (W100G) and productivity (PRODUC) obtained from the Branquinha kind as a function of organic fertilization and absence of fertilization. The values of pods length (PL), pods width (PW), dry matter (DM) number of pods per plant (NP), number of grains per plant (NG), Weight of 100 grains (W100G) and productivity (PRODUC) obtained as a function of organic fertilization, as well as the absence of fertilization for the Roxinha kind, are shown in Table 10. It can be seen that the data behaved in a similar way to that observed for Branquinha, presenting no statistical difference.
(NP), number of grains per plant (NG), weight of 100 grains (W100G) and productivity (PRODUC) obtained from the Branquinha variety due to organic and mineral fertilization. The variables Pods length (PL), pods width (PW), dry matter (DM), number of pods per plant (NP), number of grains per plant (NG), Weight of 100 grains (W100G) and productivity (PRODUC), obtained from the cultivation of the Roxinha variety according to the sources of organic and mineral fertilization, are shown in Table 12. It can be observed that there is no difference between the values found for mineral and organic fertilization. Table 12. Pods length (PL), pods width (PW), dry matter (DM), number of pods per plant (NP), number of grains per plant (NG), weight of 100 grains (W100G) and productivity (PRODUC) obtained from the variety Roxinha as a function of organic fertilization and mineal fertilization.

Table 7. Pods length (PL), pods width (PW), dry matter (DM), number of pods (NP), Number of grains (NG) and weight of 100 grains (W100G)

\begin{tabular}{|c|c|c|c|c|}
\hline \multirow[t]{2}{*}{ Fertilization } & \multicolumn{2}{|l|}{ PL $(\mathrm{cm})$} & \multicolumn{2}{|l|}{ PW (cm) } \\
\hline & $\begin{array}{l}\text { Kind } \\
\text { Branquinha }\end{array}$ & Roxinha & White & Roxinha \\
\hline DW & $7.53 \mathrm{Aa}$ & $6,80 \mathrm{Ab}$ & $1.83 \mathrm{Aa}$ & $1.67 \mathrm{Aa}$ \\
\hline $\mathrm{OC}$ & $7.33 \mathrm{Aa}$ & 6,90 Ab & $1,70 \mathrm{ABa}$ & $1.50 \mathrm{Aa}$ \\
\hline $\mathrm{DW}+\mathrm{OC}$ & $7.40 \mathrm{Aa}$ & $6.97 \mathrm{Ab}$ & $1.57 \mathrm{Ba}$ & $1.70 \mathrm{Aa}$ \\
\hline \multirow[t]{3}{*}{ Fertilization } & DM t.ha ${ }^{-1}$ & & NP plant & \\
\hline & Kind & & & \\
\hline & White & Roxinha & White & Roxinha \\
\hline DW & $2.61 \mathrm{Aa}$ & $3.32 \mathrm{Aa}$ & $47.57 \mathrm{Aa}$ & $13,40 \mathrm{Ab}$ \\
\hline $\mathrm{OC}$ & $3.05 \mathrm{Aa}$ & $3.26 \mathrm{Aa}$ & $15.33 \mathrm{Ba}$ & $4.67 \mathrm{Aa}$ \\
\hline $\mathrm{DW}+\mathrm{OC}$ & $2.20 \mathrm{Aa}$ & $3.25 \mathrm{Aa}$ & $22.60 \mathrm{ABa}$ & $3.50 \mathrm{Aa}$ \\
\hline \multirow[t]{3}{*}{ Fertilization } & NG plant & & W100G & \\
\hline & Kind & & & \\
\hline & White & Roxinha & White & Roxinha \\
\hline DW & $134.77 \mathrm{Aa}$ & $40.97 \mathrm{Ab}$ & $36.96 \mathrm{Aa}$ & $30.29 \mathrm{Ab}$ \\
\hline $\mathrm{OC}$ & $41.60 \mathrm{Ba}$ & $12.23 \mathrm{Aa}$ & $39.63 \mathrm{Aa}$ & $28,33 \mathrm{Ab}$ \\
\hline $\mathrm{DW}+\mathrm{OC}$ & $61.57 \mathrm{ABa}$ & $10.80 \mathrm{Aa}$ & $36.02 \mathrm{Aa}$ & $29,87 \mathrm{Ab}$ \\
\hline
\end{tabular}

*Averages followed by the same letter do not differ statistically between them, upper case in the column and lower case in the row, by Tukey'stest at $5 \%$ of probability. DW=Dairy Waste, $\mathrm{OC}=$ Organic Compound, DW+OC=Dairy Waste + Organic Compound.

Table 8. Productivity (PRODUC) obtained with the use of organic fertilizers and two varieties of lima beans

\begin{tabular}{lll}
\hline Fertilization & PRODUC (kg. ha-1) \\
\hline & Kind & \\
\cline { 2 - 3 } & Branquinha & Roxinha \\
DW & $1068.67 \mathrm{Aa}$ & $240,00 \mathrm{Ab}$ \\
OC & $340.67 \mathrm{Ba}$ & $67.33 \mathrm{Aa}$ \\
DW+OC & $512,00 \mathrm{ABa}$ & $67.33 \mathrm{Aa}$ \\
\hline
\end{tabular}

*Averages followed by the same letter do not differ statistically between them, upper case in the column and lower case in the row, by Tukey's $5 \%$ probability test.RL=Dairy Waste, $\mathrm{CO}=$ Organic Compound, $\mathrm{RL}+\mathrm{CO}=$ Dairy Waste + Organic Compound.

Table 9. Pods length (PL), pods width (PW), dry matter (DM), number of pods per plant (NP), number of grains per plant (NG), weight of 100 grains (W100G) and productivity (PRODUC) obtained from the Branquinha kind as a function of organic fertilization and absence of fertilization

\begin{tabular}{lllll}
\hline Variables & Treatments & & & \\
\hline & B+AT & B+DW & B+OC & B+DW+OC \\
PL (cm) & 7,43 & $7.53^{\mathrm{ns}}$ & $7.33^{\mathrm{ns}}$ & $7.40^{\mathrm{ns}}$ \\
PW (cm) & 1,87 & $1.83^{\mathrm{ns}}$ & $1.70^{\mathrm{ns}}$ & $1.57 \mathrm{~ns}$ \\
DM (t ha-1) & 2,22 & $2.61^{\mathrm{ns}}$ & $3.05^{\mathrm{ns}}$ & $2.20^{\mathrm{ns}}$ \\
NP & 44,77 & $47.57^{\mathrm{ns}}$ & $15.33^{\mathrm{ns}}$ & $22.60^{\mathrm{ns}}$ \\
NG & 122,97 & $134.77^{\mathrm{ns}}$ & $41.60^{\mathrm{ns}}$ & $61.57^{\mathrm{ns}}$ \\
W100G & 35,85 & $36.96^{\mathrm{ns}}$ & $39.63^{\mathrm{ns}}$ & $36.02^{\mathrm{ns}}$ \\
PRODUC $\left(\mathrm{kg} \mathrm{ha}^{-1}\right)$ & 866 & $1068.67^{\mathrm{ns}}$ & $340.67^{\mathrm{ns}}$ & $512.00^{\mathrm{ns}}$ \\
\hline
\end{tabular}

*, ns $=$ significant and not significant at $5 \%$ probability by Dunnett test. $\mathrm{B}=$ BranquinhaKind, $\mathrm{AT}=$ Absolute treatment,

$\mathrm{DW}=$ Dairy Waste, $\mathrm{OC}=$ Organic Compound, DW+OC=Dairy Waste+ Organic Compound.

The following variables are shown in table 11: Pod length (PL), pod width (PW), dry weight (DM), number of pods per plant (NP), number of grains per plant (NG), weight 100 grains (W100G) and productivity (PRODUC), obtained with the application of organic and mineral fertilizers in the Branquinha variety. It was observed that the values for the types of organic fertilization did not differ from those obtained by the mineral (additional testimony). Table 11. Pods length $(\mathrm{PL})$, pod width $(\mathrm{PW})$, dry matter (DM), number of pods per plant

\section{DISCUSSION}

Chemical property of the soil: From the results of the soil analysis of each treatment it was found that the minerals $\mathrm{P}$ and $\mathrm{K}$ stand out, since they are the most required for the crop and reached concentrations that would fit in high fertility soil for the State of Pernambuco (IPA, 2008). 
Table 10. Pods length (PL), pods width (PW), dry matter (DM), number of pods per plant (NP), number of grains per plant (NG), weight of 100 grains (W100G) and productivity (PRODUC) obtained from the variety Roxinha as a function of organic fertilization and absence of fertilization

\begin{tabular}{|c|c|c|c|c|}
\hline \multirow[t]{2}{*}{ Variables } & \multicolumn{4}{|c|}{ Treatments } \\
\hline & $\mathrm{R}+\mathrm{AT}$ & $\mathrm{R}+\mathrm{DW}$ & $\mathrm{R}+\mathrm{OC}$ & $\mathrm{R}+\mathrm{DW}+\mathrm{OC}$ \\
\hline PL (cm) & 6,8 & $6.80^{\mathrm{ns}}$ & $6.90^{\mathrm{ns}}$ & $6.97^{\mathrm{ns}}$ \\
\hline PW (cm) & 1,6 & $1.67^{\mathrm{ns}}$ & $1.50^{\mathrm{ns}}$ & $1.70^{\mathrm{ns}}$ \\
\hline DM (t ha-1) & 3,12 & $3.32^{\mathrm{ns}}$ & $3.26^{\mathrm{ns}}$ & $3.25^{\mathrm{ns}}$ \\
\hline NP & 16,6 & $13.40^{\mathrm{ns}}$ & $4.67^{\mathrm{ns}}$ & $3.50^{\mathrm{ns}}$ \\
\hline NG & 47,43 & $40.97^{\mathrm{ns}}$ & $12.23^{\mathrm{ns}}$ & $10.80^{\mathrm{ns}}$ \\
\hline W100G & 29,81 & $30.29^{\mathrm{ns}}$ & $28.33^{\mathrm{ns}}$ & $29.87^{\mathrm{ns}}$ \\
\hline PRODUC $\left(\mathrm{kg} \mathrm{ha}^{-1}\right)$ & 296 & $240,00^{\mathrm{ns}}$ & $67.33^{\mathrm{ns}}$ & $67.33^{\mathrm{ns}}$ \\
\hline
\end{tabular}

*, $\mathrm{ns}=$ significant and not significant at $5 \%$ probability by Dunnett test. $\mathrm{R}=$ Roxinha Kind, AT $=$ Absolute treatment, DW=Dairy Waste, OC $=$ Organic Compound, DW+OC=Dairy Waste+ Organic Compound.

Table 11. Pods length (PL), pod width (PW), dry matter (DM), number of pods per plant (NP), number of grains per plant (NG), weight of 100 grains (W100G) and productivity (PRODUC) obtained from the Branquinha variety due to organic and mineral fertilization

\begin{tabular}{|c|c|c|c|c|}
\hline \multirow[t]{2}{*}{ Variables } & \multicolumn{4}{|c|}{ Treatments } \\
\hline & $\mathrm{B}+\mathrm{MF}$ & $\mathrm{B}+\mathrm{RL}$ & $\mathrm{B}+\mathrm{CO}$ & $\mathrm{B}+\mathrm{RL}+\mathrm{CO}$ \\
\hline PL (cm) & 1,6 & $1.83^{\mathrm{ns}}$ & $1.70^{\mathrm{ns}}$ & $1.57^{\mathrm{ns}}$ \\
\hline PW (cm) & 7,33 & $7.53^{\mathrm{ns}}$ & $7.33^{\mathrm{ns}}$ & $7.40^{\mathrm{ns}}$ \\
\hline NP & 25,8 & $47.57^{\mathrm{ns}}$ & $15.33^{\mathrm{ns}}$ & $22.60^{\mathrm{ns}}$ \\
\hline NG & 77,1 & $134.77^{\mathrm{ns}}$ & $41.60^{\mathrm{ns}}$ & $61.57^{\mathrm{ns}}$ \\
\hline W100G & 39,97 & $36.96^{\mathrm{ns}}$ & $39.63^{\mathrm{ns}}$ & $36.02^{\mathrm{ns}}$ \\
\hline
\end{tabular}

*, ns= significant and not significant at $5 \%$ probability by Dunnett test. $\mathrm{B}=$ BranquinhaKind, $\mathrm{MF}=$ Mineral fertilization, $\mathrm{DW}=\mathrm{Dairy}$ Waste, $\mathrm{OC}=\mathrm{Organic}$ Compound, DW+OC=Dairy Waste+ Organic Compound.

Table 12. Pods length (PL), pods width (PW), dry matter (DM), number of pods per plant (NP), number of grains per plant (NG), weight of 100 grains $(\mathrm{W100G})$ and productivity (PRODUC) obtained from the variety Roxinha as a function of organic fertilization and mineal fertilization

\begin{tabular}{|c|c|c|c|c|}
\hline \multirow[t]{2}{*}{ Variables } & \multicolumn{4}{|c|}{ Treatments } \\
\hline & $\mathrm{R}+\mathrm{MF}$ & $\mathrm{R}+\mathrm{DW}$ & $\mathrm{R}+\mathrm{OC}$ & $\mathrm{R}+\mathrm{DW}+\mathrm{OC}$ \\
\hline PL (cm) & 6,7 & $6.80^{\mathrm{ns}}$ & $6.90^{\mathrm{ns}}$ & $6.97^{\mathrm{ns}}$ \\
\hline $\mathrm{PW}(\mathrm{cm})$ & 1,53 & $1.67^{\mathrm{ns}}$ & $1.50^{\mathrm{ns}}$ & $1.70^{\mathrm{ns}}$ \\
\hline DM (t ha- 1$)$ & 3,68 & $3.32^{\mathrm{ns}}$ & $3.26^{\mathrm{ns}}$ & $3.25^{\mathrm{ns}}$ \\
\hline NP & 16,13 & $13.40^{\mathrm{ns}}$ & $4.67^{\mathrm{ns}}$ & $3.50^{\mathrm{ns}}$ \\
\hline NG & 50,63 & $40.97^{\mathrm{ns}}$ & $12.23^{\mathrm{ns}}$ & $10.80^{\mathrm{ns}}$ \\
\hline W100G & 27,26 & $30.29^{\mathrm{ns}}$ & $28.33^{\mathrm{ns}}$ & $29.87^{\mathrm{ns}}$ \\
\hline PRODUC (kg ha $\left.{ }^{-1}\right)$ & 287,33 & $240,00^{\mathrm{ns}}$ & $67.33^{\mathrm{ns}}$ & $67.33^{\mathrm{ns}}$ \\
\hline
\end{tabular}

*, $\mathrm{ns}=$ significant and not significant at $5 \%$ probability by Dunnett test. $\mathrm{R}=$ RoxinhaKind, $\mathrm{MF}=$ Mineral fertilization,

$\mathrm{DW}=$ Dairy Waste, $\mathrm{OC}=$ Organic Compound, $\mathrm{DW}+\mathrm{OC}=$ Dairy Waste + Organic Compound.

\section{Biometric traits}

As for the Length of Pods (PL) The Branquinha has morphological characteristics superior to Roxinha (SILVA et al, 2019; SOUZA et al, 2016). And this fact is attributed to the genetic diversity among the varieties. According to Nascimento et al, (2017), the variety Roxinha presents rusticity as a characteristic. Possibly because of this fact the variety Roxinha has greater difficulty in responding to the improvement in soil fertility provided by organic fertilizers and thus not responding by increasing the width of their pods (PW). However Silva et al., (2019) showed similar values to those found in this study for the pod length and width for both evaluated varieties. The plant is dry matter is directly associated with the mineral nutrition of the crop (COSTA et al., 2007). From this information, it is possible to consider that the reason that there is no significant effect on the dry matter (DM) results is related to the fact that soil fertility levels in this study are similar for the different types of fertilization (Table 6). It is possible that organic matter decomposed more rapidly as a function of the $\mathrm{C} / \mathrm{N}$ ratio of the dairy residue, with consequent availability of the nutrients that have been absorbed by the plantis related with the increase of numbers of pods for Branquinha variety. As the crop cycle is long, it is likely that it has been able to provide the elements required for the formation of the largest number of pods. This result in favor of the Branquinha variety is supposed to be related to better soil conditioning caused by the application of dairy residue (MELO et al., 2011).
Since the number of grains (NG) is directly related to the number of pods per plant $(\mathrm{NV})$, the results were similar, which denotes a high correlation between these variables. Because the variableare interconnected (W100G) it happened in the same way with (PL) as for Gomes et al. (2010), the difference between lima beans varieties in relation to production rates is common, due to the genetic variability of the species. The results observed for the Branquinha variety in this study are within the range found by Santos et al. (2002) for the weight of 100 grains that varied from 32.6 to $79.5 \mathrm{~g}$. in eight local varieties of lima beans.

Effects of organic fertilization on productivity: The variables directly linked to productivity obtained similar responses. In all of them, the dairy waste products was highlighted as the type of fertilizer capable of positively influencing the cultivation of lima beans. In this study, considering the values obtained by the Branquinha kind, especially when fertilized with dairy waste, isolated or combined with organic compound, it was noted that productivity was higher than the average national and state yield of 328 and 354 $\mathrm{kg} \mathrm{ha}^{-1}$, respectively, in 2018 (IBGE, 2018). This value can be increased over time, with the gradual release of nutrients contained in organic fertilizers. As it is an organic fertilizer, the dairy waste releases its nutrients slowly and can better meet the crop's needs throughout its cycle. For this reason, for Yang et al. (2015), organic fertilizers should be associated with mineral fertilizers to maintain high productivity. 
Comparison of organic fertilizers with witnesses: When comparing the forms of organic fertilization with the absolute treatment (AT) for the Branquinha variety, it is noted that, possibly, the statistical similarity of these results is associated with the high levels of fertilization found for the treatments (Table 6), which was similar between the plots, leading to the availability of nutrients necessary for crop development taking into account $\mathrm{P}$ and $\mathrm{K}$. Thus, eliminating the limitations to limabeans production, as well as the possible differences between the treatments studied. According to Oliveira et al. (2004) limabeans production is directly linked to the use of phosphate fertilization due to the presence of the nutrient in the soil promoting growth and increasing production. When comparing the forms of organic fertilization with the absolute treatment for the Roxinha variety. It is understood that there was the same behavior that occurred at Branquinha kind. In the test comparing the forms of organic fertilization with mineral fertilizer for the Branquinha variety. Possibly the absorption by plants was limited due to the immediate availability of nutrients in the soil through mineral fertilizers. According to Mira et al, (2017), synthetic fertilizers have high solubility, favoring the leaching of mineral nutrients to the innermost layers of the soil, making them unavailable for cultivation. Thus, it can be said that residual fertility after cultivation contributes to the correction made previously with the sugarcane bagasse ash, as its minerals are adsorbed to organic matter. Comparing the forms of organic fertilization with mineral fertilization for the Roxinha variety. It is assumed that there was a repetition of the behavior observed for Branquinha.

\section{CONCLUSION}

Dairy waste was the fertilizer that most contributed to the increase in productivity, making it suitable for use as fertilizer. The Branquinha variety is indicated for production, because it responded better to the types of fertilizers used.

\section{REFERENCES}

Araujo, M. L. M. N., Reinaldo, L. R. L. R., Sousa, J. S., Almeida, P. G., Alves, L. S., Wanderley, J. A. C. Impactos ambientais nas margens do rio piancó causados pela agropecuária. Revista Brasileira de Gestão Ambiental, v. 4, n. 1, p. 13-33, 2010. https://www.gvaa.com.br/revista/index.php/RBGA/article/view/4 61. 20 Fev. 2020.

Azevedo, J. N., Franco, L. J. D., Araújo, R. O. C. Composição química de sete variedades de feijão-fava. Teresina: Embrapa Meio-Norte, 2003. https://www.embrapa.br/busca-depublicacoes/-/publicacao/66292/composicao-quimica-de-setevariedades-de-feijao-fava. $15 \mathrm{Fev} .2020$.

BRASIL. Ministério da Agricultura, Pecuária e Abastecimento. Regras para Análise de Sementes. Ministério da Agricultura, Pecuária e Abastecimento. Secretaria de Defesa Agropecuária. Brasília: MAPA/ACS, 2009. 395p. https://www.abrates.org.br/files/regras_analise_de_sementes.pdf. 17 Mar. 2020

Costa, C. A. D., Alves, D. S., Fernandes, L. A., Martins, E. R., Souza, I. G. B., Sampaio, R. A., e Lopes, P. S. D. N. Nutrição mineral da fava d'anta. Horticultura brasileira, v. 25, n. 1, p. 2428, 2007. https://doi.org/10.1590/S0102-05362007000100006.

Félix, C. A. Uso alternativo da adubação orgânica em substituição à mineral no cultivo do milho.Garanhuns: Universidade Federal Rural de Pernambuco,.2014. Dissertação Mestrado.

Gomes, S. O., Reis, R. L. R., DO Carmo, M. D. S., Assunção Filho, J. R., Gomes, R. L. F., \& Almeida Lopes, Â. C. Avaliação de componentes de produtividade de grãos em sub-amostras de feijão-fava de crescimento determinado. Anais da Academia Pernambucana de Ciência Agronômica, v. 7, p. 312-317, 2010. http://www.journals.ufrpe.br/index.php/apca/article/view/151. 22 Jun. 2019.

IBGE. Censo Agropecuário, Tabela 1612 - Quantidade produzida e Área colhida, por produtos da lavoura temporária - resultados
2018: IBGE, 2018. https://sidra.ibge.gov.br/tabela/ 1612\#resultado. 24 Jan. 2020.

IPA - (INSTITUTO AGRONÔMICO DE PERNAMBUCO). Recomendações de adubação para o estado de Pernambuco. 3.ed revisada. Recife, 2008.

Melo, F.P., Almeida, J.P. Análise das feições geomorfológicas e dos processos morfodinâmicos do sítio urbano de Garanhuns-PE. Ambivalências - Revista do Grupo de Pesquisa "Processos Identitários e Poder" - GEPPIP, v. 1, n.1, 2013.https://doi.org/10.21665/2318-3888.v1n1p103-114.

MELO, J. C; SANTOS, P, M, S; SANTOS, A. C; ALEXANDRINO, E. PAULA NETO, J. J. Respostas morfofisiológicas do capimmombaça submetido a doses de resíduo líquido de laticínios. Ciência Agrarias, v.54, p.247-258, 2011.https://periodicos.ufra. edu.br/index.php/ajaes/article/view/345/205. 13 Set. 2019.

Mira, A.B; Cantarella, H., Souza Neto, G.J.M., Moreira, L.A., Kamogawa, M.Y., Otto, R. Optimizing urease inhibitor usage to reduce ammonia emission following urea application over crop residues. Agrculture, Ecosystems \& Environment, v. 248, p. 105112, 2017.https://doi.org/10.1016/j.agee.2017.07.032.

Motta-Aldana, J.R; Serrano-Serrano, M.L., Hernandez-Torres, J., Castillo-Villamizar, G. Multiple domestications of the Mesoamerican gene pool of lima bean (Phaseolus lunatus L.): evidence from chloroplast DNA sequences. Genetic Resources and Crop Evolution, v. 60, n. 3, p. 1069-1086, 2013. https://link.springer.com/article/10.1007/s10722-012-9904-9. 10 Nov. 2019.

Nascimento, M. D. G. R., Alves, E. U., Silva, M. L., e Rodrigues, C. Lima bean (Phaseolus lunatus L.) seeds exposed to different salt concentrations and temperatures. Revista Caatinga, v. 30, n. 3, p. 738-747, 2017. https://doi.org/10.1590/1983-21252017v30n32 2 rc.

Oliveira, A. E. S., Simeão, M; mousinho, F. E. P; Gomes. R. L. F. Desenvolvimento do feijão-fava (Phaseuluslunatus L.) sob déficit hídrico cultivado em ambiente protegido. HOLOS, v. 1, p. 143151, 2014. http://www2.ifrn.edu.br/ojs/index.php/HOLOS/ article/view/1867. 14 Ago. 2019.

Oliveira, A. P. D., Alves, E. U., Alves, A. U., Dornelas, C. S., Silva, J. A. D., Pôrto, M. L., Alves, A. V. Produção de feijãofava em função do uso de doses de fósforo. Horticultura Brasileira, 2004, 543-546. https://doi.org/10.1590/S010205362004000300008 .

Pegado, C. M. A., Barbosa, L. J., Mendes, J. E. M. F. M., Souto, P. C., Souto, J. S. Decomposição superficial e subsuperficial de folhas de fava (PhaseoluslunatusL.) na região do Brejo da Paraíba, Brasil. Revista Caatinga, v. 21, n. 1, 2008. https://periodicos.ufersa.edu.br/index.php/caatinga/article/view/63 1. 20 Abr. 2019.

Santos, D., Corlett, F. M. F., Mendes, J. E. M. F., Júnior, J. S. A. W. Produtividade e morfologia de vagens e sementes de variedades de fava no Estado da Paraíba. Pesquisa Agropecuária Brasileira, $\begin{array}{lllll}\text { v. } 37, \quad \text { n. } 10, \quad \text { p. } 1407-1412, & 2002 .\end{array}$ http://www.scielo.br/pdf/pab/v37n10/13219.pdf. 11 Out. 2019.

Santos, E. S., Macêdo, L.S., Matias, E.C., Barbosa, M.M. Resposta da cultura do inhame à fertilização com macro e micronutriente em um Argissolo Vermelho-Amarelo Distrófico arênico. Tecnologia e Ciência Agropecuária, v3, n3, p. 39-46, 2009.http://revistatca.pb.gov.br/edicoes/volume-03-2009/volume3-numero-3-setembro-2009/tca08_inhame_adubacao.pdf. 19 out. 2019.

SANTOS, H. G. et al. Sistema brasileiro de classificação de solos. [s.l: s.n.]. SILVA, C. H. C., ROCHA, F. C., SILVA, L. L. G. G. Production of organic compost from different plant waste generated in the management of a green urban space. RevistaCiênciaAgronômica, v. 49, n. 4, p. 558-565, 2018.

Santos, P. M., Santos, C. A., Silva, C. E. J. Resíduo de laticínio em pastagem de capim Mombaça: atributos químicos da forragem e do solo. Semina: Ciências Agrárias, v. 34, n. 1, 2013. http://srv009.uel.br/revistas/uel/index.php/semagrarias/article/download/10 488/12060. 12 Jun. 2019.

Silva, C. H. C; Rocha, F. C; Silva, L. L. G. G. Production of organic compost from different plant waste generated in the management 
of a green urban space. Revista Ciência Agronômica, v. 49, n. 4, p. 558-565, 2018. https://doi.org/10.5935/1806-6690.20180063.

Silva, S. I. A., Souza, T., Santos, D., Silva Souza, R. F. Avaliação dos componentes de produção em variedades crioulas de fava cultivadas no Agreste da Paraíba. Revista de Ciências Agrárias, v. 42, n. 3, p. 731-742, 2019.https://doi.org/10.19084/rca.16956.

Souza, J. D. S., Rodrigues, L. N., Souza, J., Sales, L., Nascimento, N. Caracterização morfoagronômica de feijão fava. In: Congresso Técnico Científico da Engenharia e da Agronomia, 73a Semana da Engenharia e da Agronomia. Foz do Iguaçu-PR. 2016. http://www.confea.org.br/sites/default/files/uploads-

imce/contecc2016/agronomia/caracteriza $\% \mathrm{C} 3 \% \mathrm{~A} 7 \% \mathrm{C} 3 \% \mathrm{~A} 3 \mathrm{o} \% 2$ 0morfoagron $\% \mathrm{C} 3 \% \mathrm{~B} 4 \mathrm{mica} \% 20 \mathrm{de} \% 20$ feij $\% \mathrm{C} 3 \% \mathrm{~A} 3 \mathrm{o} \% 20$ fava.pd f. 14 Jul. 2019.
Vale, J.C; Bertini, C., Borém, A. Feijão-caupi: do plantio à colheita. Viçosa, Ed. UFV. 267p. 2017

Yang, J., Gao, W., \&Ren, S. Long-term effects of combined application of chemical nitrogen with organic materials on crop yields, soil organic carbon and total nitrogen in fluvo-aquic soil. Soil and Tillage Research, v. 151, p. 67-74, 2015. https://doi.org/10.1016/j.still.2015.03.008. 